\title{
НОВЫЕ ПОДХОДЫ К СИНТЕЗУ И МОДИФИКАЦИИ 4Н-ХРОМЕНОВ И БЕНЗОФУРАНОВ КАК ПОТЕНЦИАЛЬНЫХ АНТИГЛИКЕМИЧЕСКИХ АГЕНТОВ
}

\author{
В.А. Осянин, Д.В. Осипов, И.А. Семёнова, К.С. Корженко, \\ М.Р. Демидов, Ю.Н. Климочкин
}

Химико-технологический факультет, Самарский государственный технический университет, 443100, Россия, г. Самара, ул. Молодогвардейская, 244.

DOI: 10.19163/MedChemRussia2021-2021-22

E-mail:VOsyanin@mail.ru

В настоящее время для лечения диабета 2-го типа одобрены три лекарственные препарата (акарбоза, миглитол, воглибоза), являющиеся ингибиторами $\alpha$-глюкозидазы, принцип действия которых основывается на конкурентном ингибировании фермента и замедлении высвобождения глюкозы из сложных углеводов. Однако большое количество побочных эффектов и недостаточная гипогликемическая активность обуславливает необходимость поиска новых соединений с данным типом активности. Недавно среди (дигидро) бензофуранов и 4Н-хроменов, которые родственны некоторым флавоноидам, нами были выявлены эффективные ингибиторы $\alpha$-глюкозидазы $[1,2]$.
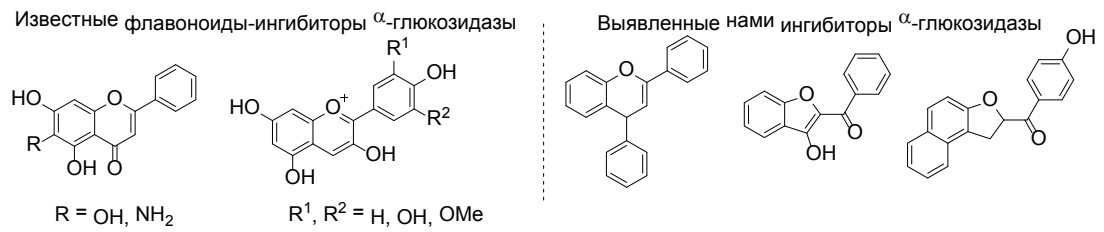

В докладе будут рассмотрены два основных подхода к получению указанных классов соединений. Первый заключается в формальном [4+1]-циклоприсоединении к о-хинонметидам синтетических эквивалентов ацилкарбенов с образованием 2-ацил-2,3-дигидробензофуранов и последующей их

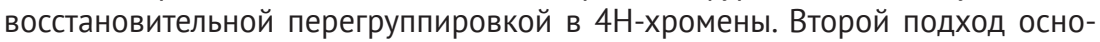
ван на реакции Дильса-Альдера между о-хинонметидами и высокополяризованными (пуш-пульными) олефинами. Кроме того, будет уделено внимание

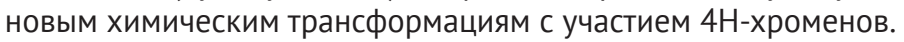

Работа выполнена при финансовой поддержке Российского научного фонда (грант 19-13-00421).

\section{Литература}

[1] A.A. Spasov, D.A. Babkov, T.Y. Prokhorova, E.A. Sturova, D.R. Muleeva, M.R. Demidov, D.V. Osipov, V.A. Osyanin, Y.N. Klimochkin, Chem. Biol. Drug Design. 2017, 90, 1184-1189.

[2] A.A. Spasov, D.A. Babkov, D.V. Osipov, V.G. Klochkov, D.R. Prilepskaya, M.R. Demidov, V.A. Osyanin, Y.N. Klimochkin, Bioorg. Med. Chem. Lett. 2019, 29, 119-123. 